\title{
Factors that Influenced Effective of Employees Performance, Faculty of Management Technology
}

\author{
Jantira Phooma, Chulin Tongumpa, and Thanatcha Suriyawong
}

\begin{abstract}
The research objectives were to study factors that influenced of operation success and the behavior that affected effective of employees performance which provide 100 employees, Faculty of Management Technology, Rajamangala University of Technology Srivijaya. The research tool was questionnaires by collected data from staff of Faculty of Management Technology. The statistics used to determine the quality of questionnaires by finding the confidence such as percentage, mean, standard deviation and test hypotheses for finding the relationship between variables by analyzing the correlation coefficient and multiple regression analysis. The study found that the most respondents were female equals 77.0 percent, 23.0 percent were males. Ages between 22-45 years old, education level as bachelor degree equals 52.0 percent, 54 percents provide a university position is employed. The test result of hypothesis showed that the overall of personnel demographic influenced of operation performances. Information of workplace behavior of staffs showed that the high level of overall of workplace behavior as 3.35 who largely as a faithfulness person as $\mathbf{4 . 3 8}$, a willingness to practice work assignments as $\mathbf{4 . 3 1}$, a diligence person and patience as $\mathbf{4 . 2 3}$, providing a screening, checking information to determine and carefully decision and sensibly respectively.
\end{abstract}

Index Terms-Employee, behavior, effective, factor.

\section{INTRODUCTION}

Currently, high competition in the workplace has been increasingly evident. Both government and private sectors have implemented reorganization by adopting technology into their organization to respond to the changing society. In order to run work smoothly, the employees of organizations must encompass high quality and work efficiently. It is argued here that in order to do so, it is not merely the employees' knowledge level and ability but that their working behavior is also significant for performance efficiency in an organization.

There are two main types of working behavior: positive and negative one. Employees with positive working behavior normally show high attention, dedication, overtime working, punctuality, assertiveness in expressing opinions to their office heads, good problem-solving ability and concentration in meetings, which lead to successful and efficient job performance in an organization. On the other hand, those employees with negative working behavior show different behavior, for example playing games at workplace, loudly chatting, using online media while working, being irresponsible and not being punctual. These negative ones

Manuscript received November 11, 2013; revised January 28, 2014.

Jantira Phooma is with the Rajamangala University of Technology Srivijaya, Thailand (e-mail: jan_phooma@hotmail.com). will affect their work efficiency and consequently lead to failing to achieve organization goals.

In addition, performance behavior, a connection between each other through social media is a way to provide more convenient to command in the organization. So, that staffs treat them achieve their goals quickly.

In 5 years ago, rapidly of growth and progression in computer technology, internet network have changed the way of life, behavior, business operating and society connection Researchers have indicated that a media or communication tool which has been popular at the different periods influenced on the thinking and could be an importance factor to frame the idea and understanding the world around us.

Currently, internet users around the world with nearly two billion people on June, 2010 (Internet World Stats, 2010). Internet has became the largest place in the world to share and exchange an information that cause of change in communication style from original communication to using communication technology in virtual world which hold of limitless communications. So, many people around the world have taken both in the social world and virtual world [1].

In the present, online communications has developed rapidly and define for changing lifestyle of consumers. It provides a new communication channel that result of an success for people in work of the new era.

Factors that influenced of operation success and behavior that affected effective of employees Faculty of Management Technology, Rajamangala University of Technology Srivijaya which using information to improve and enhance employees operation.

\section{RESEARCH OBJECTIVE}

For study the factors that influenced of operation success and behavior that affected effective of employees Faculty of Management Technology, Rajamangala University of Technology Srivijaya.

\section{LITERATURE REVIEW}

Behavior is attributes or identification of the organism. Haman factor is one important factor in several of organizations to perform together as one for achieving the goal. Success or failure depends on the person not what the administration will have their own ways because each person is made up of a group of people that all have their different natural of personality, needs and values. Executive management is person who responsible and provide participation in management process which cover on plan, management and guidance of under the supervisor [2]. 
Behavior do not occur and change due to only environments factors but personal factors has to be deal (cognitive, biological and others) and include with behavior and environment factors [3].

Behavior refers to processes of group operation that called administrators which for purpose of education management to members in the society. Several of operations will follow a defined social system.

Cognitive Behavior Therapy [4] is a process for changing external behavior through changing of thinking, interpretation, underlying assumption, or know in namely cognitive changing for external behavior which behavioral beliefs as follow:

1) Intellectual activities affect an external behavior

2) Activities and changing of activities conducted to provide an intellectual activities

3) Changing of external behavior may be a result of cognitive changing by managing of internal behavior behavior refers to processes of group operation that called administrators which for purpose of education management to members in the society. Several of operations will follow a defined social system.

Social networking as known as "Social Media" is a tool which allows peoples to exchange information quickly and efficiently with others in society. Furthermore, It is a tools of organizations to be use in advertising with target groups because social networking are creating a group with common interested. Thus, joining the group that indicated the need for receiving information [5].

Research of Edelman Trust Borometer in 2008 was noted that the appearing many information on the internet do not provide an good filtering system. People in the group have tended to trust that information from others more than believe information which found on another website [6].

\section{Methodology}

\section{A. Research Tools}

Data collection tools such as questionnaires about study of relationship between working factors and employees operation success, Faculty of Management Technology. Section I provides general information. Section II shows information of behavior of employees operation. Section III indicates information of working ethics of employees. Section IV provides information of result of employees performance and Section $\mathrm{V}$ indicates information of effective of operation employees by divide into $\mathrm{V}$ classes interval.

Data analyzing, taking marks through evaluation for finding mean of marks by using formula [7].

\section{B. Data Collection}

Researchers collected data from samples of 100 employees of Faculty of Management Technology by divide data into II categories as follow:

1) Primary data from 100 populations which provide from employees of Faculty of Management Technology.

2) Secondary data collected from searching by computer, textbook and researches.

\section{Data Analysis}

The research instrument used in the data collection was a questionnaire to examine the relationship between working factors and performance success of the employees at the Faculty of Management Technology, Rajamangala University of Technology Srivijaya. Then the arithmetic mean was used to analyze data and interpret findings [8].

\section{FINDINGS AND ANALYSIS}

TABLE I: GENERAL ANALYSIS OF RESPONDENTS

\begin{tabular}{lll}
\hline \hline Gender & Samples & Percentage \\
\hline Male & 23 & 23 \\
Female & 77 & 77 \\
Total & 100 & 100 \\
\hline \hline
\end{tabular}

Table I found that the majority of respondents were women equaled 77 percent and male equaled 23 percent.

TABLE II: INFORMATION ABOUT PERIOD OF WORKING

\begin{tabular}{lll}
\hline \hline Academic Position & Samples & Percentage \\
\hline Lecturer (Civil Servant) & 16 & 16 \\
Lecturer (University Employees) & 25 & 25 \\
University Employees & 17 & 17 \\
Government Employees & 1 & 1 \\
University Staffs & 21 & 21 \\
Research Assistant & 20 & 20 \\
Total & 100 & 100
\end{tabular}

Table II found that the most of respondents, 25 people equaled 25 percent were a lecturer (university employee). Following by university staff equaled 21 percent. Next, research assistant equaled 20 percent. Then, University employee equaled 17 percent. Finally, lecturer (civil servant) equaled 16 percent.

TABLE III: INFORMATION ABOUT EDUCATION LEVEL

\begin{tabular}{lll}
\hline \hline Education Level & Samples & Percentage \\
\hline Bachelor degree & 65 & 65 \\
Master degree & 10 & 10 \\
Doctoral degree & 10 & 10 \\
Total & 100 & 100 \\
\hline \hline
\end{tabular}

Table III showed the most of that respondents provided bachelor degree 65 people equals 65 percentage. Next, they were taking master degree 25 people equals 25 percentage, and doctoral degree that on studying process were 10 people equal 10 percentages.

TABLE IV: INFORMATION ABOUT PERIOD OF WORKING

\begin{tabular}{lll}
\hline \hline Working period & Samples & Percentage \\
\hline Less than 5 years & 79 & 79 \\
5-10 years & 7 & 7 \\
10-15 years & 1 & 1 \\
More than 15 years & 13 & 13 \\
Total & 100 & 100 \\
\hline \hline
\end{tabular}

Table IV found that the most of respondents provided 
period of working less than 5 years equals 79 percentages. Next, Containing more than 15 years of period of working equals 13 percentages, period of working 5-10 years equals 7 percentage and who working between $10-15$ years equals 1 percentage.

TABLE V: THE AVERAGE AND STANDARD DEVIATION OF STAFF WORKING ETHIC

\begin{tabular}{|c|c|c|c|}
\hline Working Ethic & $\bar{x}$ & S.D. & $\begin{array}{l}\text { Descriptive } \\
\text { Level }\end{array}$ \\
\hline $\begin{array}{l}\text { Listen to other opinions } \\
\text { of those concerned and } \\
\text { improve their job } \\
\text { performance after } \\
\text { receiving suggestions }\end{array}$ & 4.23 & 0.68 & High \\
\hline $\begin{array}{l}\text { Be able to coordinate, } \\
\text { work as a team and build } \\
\text { working network well }\end{array}$ & 3.99 & 0.53 & High \\
\hline $\begin{array}{l}\text { Always give others an } \\
\text { opportunity to make a } \\
\text { decision }\end{array}$ & 4.08 & 0.62 & High \\
\hline $\begin{array}{l}\text { Treat others equally and } \\
\text { fairly }\end{array}$ & 3.94 & 0.66 & High \\
\hline $\begin{array}{l}\text { Participate in making a } \\
\text { decision } \\
\text { activities }\end{array}$ & 4.03 & 0.61 & High \\
\hline Value the majority voice & 4.10 & 0.65 & High \\
\hline $\begin{array}{l}\text { Perform jobs with } \\
\text { professional integrity }\end{array}$ & 4.05 & 0.62 & High \\
\hline $\begin{array}{lr}\text { Utilize } & \text { resources } \\
\text { efficiently } & \text { and } \\
\text { reasonably } & \end{array}$ & 4.08 & 0.62 & High \\
\hline $\begin{array}{l}\text { Be able to meet a } \\
\text { deadline }\end{array}$ & 4.36 & 0.64 & High \\
\hline $\begin{array}{l}\text { Develop work for the } \\
\text { quality output }\end{array}$ & 4.16 & 0.66 & High \\
\hline $\begin{array}{l}\text { Coordinate work with all } \\
\text { sectors }\end{array}$ & 3.92 & 0.65 & High \\
\hline Work diligently & 4.12 & 0.58 & High \\
\hline Work honestly and fairly & 4.25 & 0.68 & High \\
\hline $\begin{array}{l}\text { Work with politeness and } \\
\text { generosity }\end{array}$ & 4.31 & 0.64 & High \\
\hline Total & 4.10 & 0.63 & High \\
\hline
\end{tabular}

\section{DISCUSSION}

Majority of staff are young generation who can use online media as a part of living that take cooperating on time. It affected for increasing of efficiency on working behavior in order to information communication up to date.

The research findings in relation to working ethics which affected efficiency in staff work performance suggest that most employees lacked the courage to make a decision and to preserve professional integrity, followed by lacking communication and working together to coordinate others from related sectors to achieve the mission. Other aspects which might affect job performance required close investigation into each items with arithmetic means. It was found that some aspects were problematic for staff's job performance. However, considering the efficiency of staff's job performance at the Faculty of Management Technology, the findings indicated that their time efficiency was valued mostly. That is, the employees could accomplish work to meet a deadline. This finding was consistent with that in [9]which examined personal factors and factors that affected the work performance of staff function, a case study of pesticide manufacturers of industrial estate in Wellgrow Industrial Estate, indicating that the employees values time efficiency of job performance mostly, followed by the quality and quantity of work respectively[10]-[14].

\section{ACKNOWLEDGMENT}

The researchers of this study "Behaviors and ethics affecting efficiency of staff performance at Faculty of Management Technology, Rajamangala University of Technology Srivijaya" are grateful to Faculty of Management Technology, Rajamangala University of Technology Srivijaya for research fund allocation and facilitation which has made this research completed as in its objectives.

\section{REFERENCES}

[1] Katiya Saisaree (2011). What is Social Networking. [Online]. Available: http://keng.com/2011/03/10/what-is-social-network/

[2] R. Wisatsang, "Transformational leadership," Application Development, vol. 13, no. 116, pp. 18-24.

[3] A. Bandura, "Social cognitive theory," Annals of Child Development, 5th ed, pp. 48-49, 1986.

[4] A. E. Kazdin, "Acceptability of timeout from reinforcement procedures for disruptive child behavior," Behavior Therapy, vol. 11, pp. 329-344, 1978

[5] P. Vora, Web Application Design Patterns, Morgan Kaufmann. Burlington, Massachusetts, USA, 2009, pp 259-310.

[6] B. Alexander. (2006). Web 2.0 a new wave of innovation for teaching and learning. EDUCAUSE Review. [Online]. pp. 33-44. Available: http://www.education.edu/ir/library/pdf/erm0621.pdf

[7] K. Vanichbuncha, Using of SPSS for Window in Data Analyzing, Chulalongkorn University Press, 4th ed, 2003.

[8] K. Vanichbuncha, "Statistic analysis," Statistic for Administration ANS Research, 7st ed., Bangkok, Thailand, 2003.

[9] K. Yammeng, "The Individual and working factors affecting to staff working performance, a case study of an insecticide production company in wellgrow industrial estate, Chachoengsao Province," Master dissertation, Graduate School of Commere., Burapha Univ., 2010.

[10] G. Armstrong and P. Kotler, Marleting and Introduction, 6st ed. New Jerey, USA: Pearson Education, 2003.

[11] N. Kinawong, Genealogieal writing principles and basics of administration and student supervision Texas, pp. 12, 1980.

[12] A. J. Newman and P. Cullen, Retailing Environment and Operations, 6st ed., Australia: Saxon Graphic, 2002.

[13] P. Lenukool, "Boredom in working and working effeciency of supporting staff," Faculty of Nursing, Prince of Songkla Univ., 2009.

[14] S. Chanpetch, "Working performance of subdistrict headman, village headman with outstanding work performance, A case study of Mueang Satun Distric, Satun Province," Master dissertation, Prince of Songkla Univ., 2011.

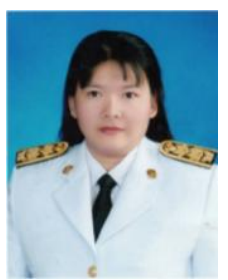

Jantira Phooma was born on May 3, 1971 in Nakhon Si Tammarat Province. In 1995, she was graduated in bachelor degree of information technology, Rajamangala Institute of Technology. After that, She was pursued master degree in business administration from Ramkhamhaeng University, Bangkok, Thailand in 2001 .

She joined with Rajamangala University of Technology Srivijaya more than 10 years as a lecturer. In the present, she is a senior lecturer in information technology program, Faculty of Management Technology, Rajamangala University of Technology Srivijaya. In additional, she used to be an deputy dean of academic office for Faculty of Management Technology from 2009 to 2013. 


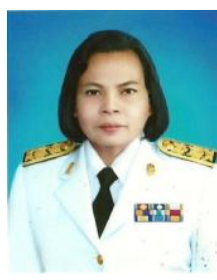

Chulin Thongampa was born in Nakhon S Tammarat province in 1956. In 1988, she was graduated in bachelor degree of business administration (marketing), Rajamangala Institute of Technology. After that, she was completed master degree in education program in Educational Administration, Ramkhamhaeng University, Bangkok, Thailand in 2000 .

She joined with Rajamangala University of Technology Srivijaya more than 15 years as a lecturer. In the present, she is a senior lecturer in marketing program, Faculty of Management Technology, Rajamangala University of Technology Srivijaya.

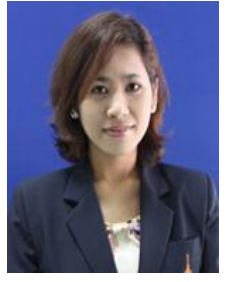

Thanatcha Suriyawong was born on December 5 1984 in Bangkok, Thailand. In 2007, she was graduated in bachelor degree of business administration (accounting), Prince of Songkla University. After that, she was pursued master degree in Business Administration (Finance) from Universiti Utara Malaysia, Malaysia in 2010.

She joined with Rajamangala University of Technology Srivijaya from 2011- present as a lecturer. In the present, she is a lecturer in accounting and finance program, Faculty of Management Technology, Rajamangala University of Technology Srivijaya. 